\title{
Coastal water darkening and implications for mesopelagic regime shifts in Norwegian fjords
}

\author{
Dag L. Aksnes ${ }^{1, *}$, Nicolas Dupont ${ }^{1}$, Arved Staby ${ }^{1}$, Øyvind Fiksen ${ }^{1}$, \\ Stein Kaartvedt ${ }^{2}$, Jan Aure ${ }^{3}$ \\ ${ }^{1}$ Department of Biology, University of Bergen, 5020 Bergen, Norway \\ ${ }^{2}$ Department of Biology, University of Oslo, 0316 Oslo, Norway \\ ${ }^{3}$ Institute of Marine Research, 5817 Bergen, Norway
}

\begin{abstract}
The light regime of the water column has a strong structuring effect on aquatic food webs and it has been previously hypothesized that coastal water darkening has increased the success of tactile predators relative to visual predators such as fish. Due to a general lack of time-series of optical parameters, we applied a proxy for light attenuation that depends on salinity and dissolved oxygen at a time of the year when chlorophyll concentrations were low. We present evidence that coastal waters of Norway have darkened as a result of freshening over the period 1935 to 2007. Our results suggest that locations where coastal water penetrates into deep basins have been prone to water column darkening, particularly if dissolved oxygen has also declined. We have estimated that salinity and oxygen variation on the ranges 33 to $35 \mathrm{PSU}$ and 1 to $6 \mathrm{ml} \mathrm{O}_{2} \mathrm{l}^{-1}$ are associated with up to 8 orders of magnitude difference in photon flux at $200 \mathrm{~m}$ depth in a water column devoid of pigments. Our results suggest such darkening needs to be considered in analyses of mesopelagic regime shifts involving mass occurrence of the jellyfish Periphylla periphylla.
\end{abstract}

KEY WORDS: Light attenuation - Regime shift - Freshening - Darkening - Coastal ecosystems

\section{INTRODUCTION}

Effects of human activities such as fishing, nutrient releases, and changes in freshwater runoff are believed to have transformed coastal ecosystems long before modern ecological investigations began (Jackson 2001). Although an increasing number of variables are being monitored in coastal waters, time-series of potentially important environmental drivers are still lacking and this makes causal analyses of observed changes unreliable. Water column light attenuation is a particularly critical ecosystem variable. This is not only due to its effect on primary production, but also because most animals are sensitive to light. This sensitivity includes light intensities several orders of magnitude below that required for photosynthesis (Frank \& Widder 1994, Holzman \& Genin 2005, Hernandez-Leon 2008). Shortterm changes in the light regime of coastal areas might be considerable (Frette et al. 2004, Gallegos et al. 2005), but little is known about long-term changes and consequences. Apart from Secchi disc observations (Falkowski \& Wilson 1992, Sanden \& Håkansson 1996, Aksnes \& Ohman 2009) long time-series of marine optical properties do not exist. The usefulness of Secchi disc observations is limited because they provide information about surface water only. Proxies of light attenuation would therefore be useful in analyses of environmental change involving e.g. declines in fish stocks (Aksnes 2007, Daskalov et al. 2007), submerged aquatic vegetation (Kemp et al. 2004), nitracline (Aksnes et al. 2007) and euphotic zone shoaling (Aksnes \& Ohman 2009), and biodiversity changes in general (Jackson 2001). Such changes could then be analysed in a wider perspective than allowed by commonly monitored variables such as temperature.

It is well-known that coastal water attenuates light more than oceanic water does (Jerlov 1968). This is partly due to higher concentrations of particulate mat- 
ter (such as phytoplankton), but also because of dissolved organic matter (DOM) in the freshwater component of coastal water (Aarup et al. 1996, Højerslev et al. 1996, Helms et al. 2008). This tends to give a negative correlation between light attenuation and salinity, and salinity is therefore a potential proxy for light attenuation. In stark contrast to the general lack of optical time-series, measurements of salinity are incorporated in any routine marine investigation. If precipitation and runoff affect salinity, e.g. as a result of climate change (Greene et al. 2008), we should also expect changes in the coastal light regimes with possible ecosystem implications (Pozdnyakov et al. 2007).

A long-term freshening of the Norwegian Coastal Water (NCW) has been connected to increased precipitation and runoff in Northern Europe and increased southwesterly winds associated with a high North Atlantic Oscillation (NAO) (Sætre et al. 2003, Sætre 2007). Here we explore whether this freshening might have contributed to a higher light attenuation of the mesopelagic habitat of Norwegian fjords. Previous evidence suggests that light absorption tends to increase with oxygen depletion (Sørnes \& Aksnes 2006), therefore we also explore how water column darkening relates to variations in dissolved oxygen. This is potentially important because decreased dissolved oxygen in subsurface water follows eutrophication and has resulted in oxygen depletion in coastal areas and shelf regions worldwide (Diaz 2001), including coastal regions of Scandinavia (Aure et al. 1996, Johannessen \& Dahl 1996, Nordberg et al. 2000).

Potential implications of variation in optical properties on food web structure are illustrated in 2 well-studied fjords (Masfjorden and Lurefjorden) that serve as models in the present study (Fig. 1). Lurefjorden is much darker than Masfjorden (Eiane et al. 1999, Sørnes \& Aksnes 2006). The 2 main zooplanktivores in Masfjorden are the mesopelagic fishes Maurolicus muelleri and Benthosema glaciale, while such visual predators are practically absent in Lurefjorden. Instead there is a total dominance of the jellyfish Periphylla periphylla and other tactile invertebrate predators (Eiane et al. 1999, Bagøien et al. 2001, Sørnes et al. 2007). Evidence suggests that Lurefjorden has not always been suitable to $P$. periphylla, since the mass occurrence apparently was established in the 1970s (Fosså 1992). It has been hy- pothesized that a gradual NCW darkening has caused this apparent regime shift by affecting light conditions in favour of tactile predators (Eiane et al. 1999, Sørnes et al. 2007). In recent years there has been an apparent increase in the number of Norwegian coastal locations where such mass occurrences have been observed (J. A. Sneli, C. Schander \& K. Eiane pers. comm.). We test here the hypothesis that the water column of Lurefjorden has darkened as a result of the long term NCW-freshening (Sæetre et al. 2003, Sæetre 2007).

Our study consists of 3 parts. Firstly, we establish an empirical relationship between light attenuation on one hand and salinity, dissolved oxygen and chlorophyll on the other. This relationship is based on observations made in fjords along the western coast of Norway at a time of the year when solar radiation and chlorophyll concentrations are low. Secondly, we apply the empirical relationship to salinity measurements of the NCW that extend back to 1935 to estimate longterm increase in the light attenuation of the 2 coastal locations, Lurefjorden and Masfjorden. Finally, we discuss whether the apparent mesopelagic regime shift in Lurefjorden is consistent with the 'darkening hypothesis.'

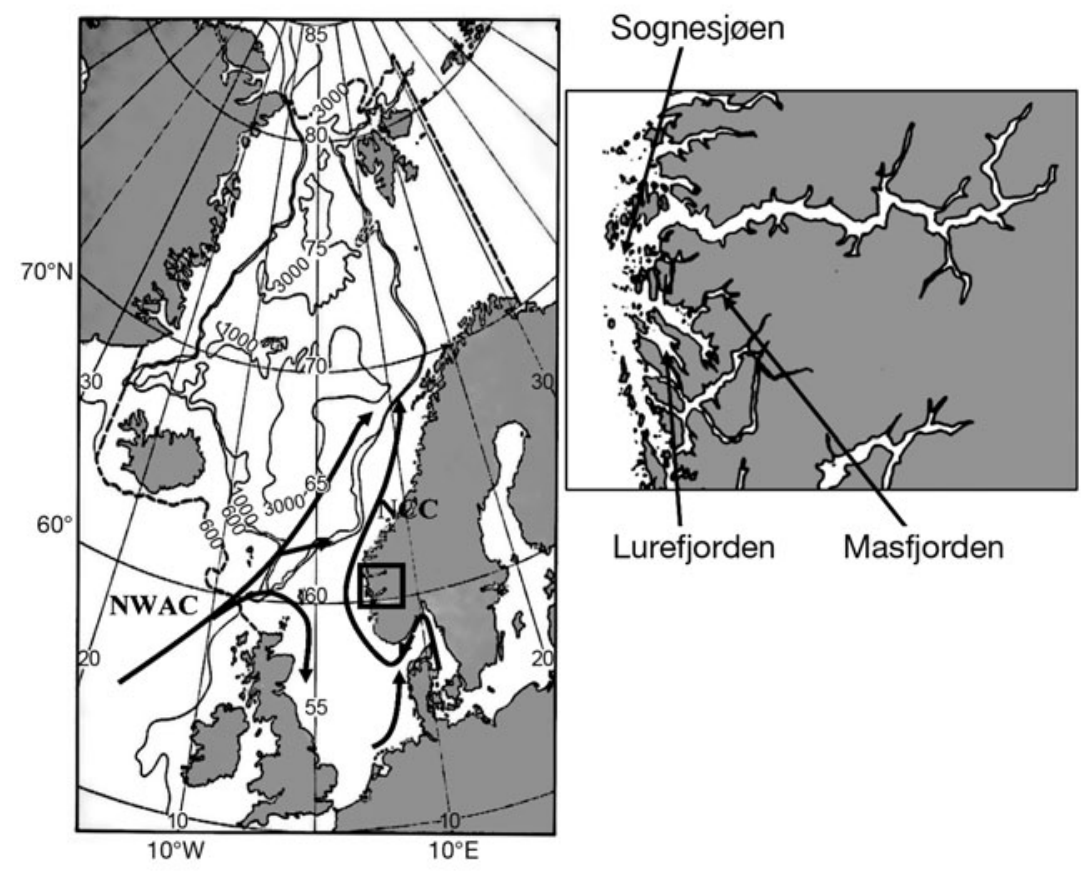

Fig. 1. Location of Sognesjøen hydrographical station $\left(61^{\circ} 01.4^{\prime} \mathrm{N}, 4^{\circ} 50.4^{\prime} \mathrm{E}\right)$, which has operated since 1935. The Norwegian Atlantic Current (NWAC) transports saline North Atlantic Water (NAW) into the Norwegian Sea, whereas the Norwegian Coastal Current (NCC) transports less-saline Norwegian Coastal Water (NCW) from the North Sea northwards along the Norwegian coast. NAW is dense and submerges below NCW, and intrudes into fjords where the sill depth is deeper than the thickness of the NCW. In Lurefjorden, NAW does not intrude because of a shallow sill $(20 \mathrm{~m})$, while Masfjorden has a deeper sill $(75 \mathrm{~m})$ that allows regular intrusions of NAW 


\section{MATERIALS AND METHODS}

Measurements of downwelling irradiance in Lurefjorden and Masfjorden. During a cruise with RV 'Trygve Braarud' $2 \mathrm{wk}$ prior to the main field campaign, downwelling irradiance was measured with a Trios RAMSES ACC hyperspectral radiometer in Lurefjorden (11 October 2006) and Masfjorden (6 October 2006) from the surface down to approximately $80 \mathrm{~m}$ depth. Observations were made every meter down to $10 \mathrm{~m}$, and every $5 \mathrm{~m}$ thereafter. We compared the attenuation coefficient for downwelling irradiance, $K_{d}(500)$, with measurements of absorption, $a_{m}(500)$, in collected unfiltered water samples (see below). For this purpose, $K_{d}(500)$ for a particular depth $(z)$, where $a_{m}(500)$ was measured, was calculated as the attenuation of downwelling irradiance in the depth segment $z-5$ to $z+5 \mathrm{~m}$.

Measurements of light absorption. From 29 October to 5 November 2006 a cruise was conducted with RV 'Håkon Mosby' along the western coast of Norway. Water samples were collected with 12 l rosettemounted Niskin water collectors and sampling spanned the range 0 to $1200 \mathrm{~m}$ depth (Table 1). Simultaneous measurements of salinity, temperature and dissolved oxygen were obtained with a Seabird SBE 911 CTD (Sea-Bird Electronics). The water samples were acclimatized to room temperature and light absorbance was measured at 400,420,440,450,460,480, 500 and $550 \mathrm{~nm}$ with a spectrophotometer (UV/VIS Spectrometer Lambda 2, Perkin Elmer). The purpose of these measurements was to obtain a proxy for light attenuation at great depths. The water samples were not filtered and consequently our modified absorbance measurements include scattering and absorption from particles (such as phytoplankton) that otherwise would have been removed by filtering. Although the particle content is low at this time of the year, particulate scatter and absorption would have contributed to a higher apparent absorbance; we have therefore used the symbol $a_{m}$ instead of the conventional a for absorption. A total of 8 absorbance readings were made for each depth; 2 successive readings were made in a $10 \mathrm{~cm}$ quartz cuvette and 2 cuvettes were taken from 2 separate water samples. The blank control contained distilled freshwater purified with a Millipore Simplicity 185 Water Purification System. Our modified absorption measurement, $\left[a_{m}(\lambda), \mathrm{m}^{-1}\right]$, at wavelength $\lambda$, was calculated from absorbance, $a_{m}(\lambda)=2.303 A(\lambda) / 0.1$, according to $a_{m}(\lambda)$. We fitted the exponential function

$$
a_{m}(\lambda)=C \mathrm{e}^{-k_{m} \lambda}
$$

to the wavelength specific absorption values obtained at each depth by use of linear regression on the logtransformed absorption. Here $C$ is a constant and $k_{m}$ is the spectral slope factor. As for $a_{m}$, this coefficient will also be affected by particle absorption and scattering. Particles could potentially also introduce variation during a scan, resulting in a poor fit when fitting Eq. (1), but only 1 out of 71 different sampling depths gave $\mathrm{r}^{2}<0.95$. The reported modified absorption values $\left(a_{m}[500]\right)$ represent the regression estimate that was obtained for insertion of $500 \mathrm{~nm}$ in Eq. (1) for each sampled depth. We apply this wavelength, rather than the lower wavelengths used in chromophoric DOM (CDOM) studies, because we investigate effects on downwelling irradiance at great depths where $500 \mathrm{~nm}$ is representative for the deepest penetrating wavelengths. For the clearest water, the absorbance measurements at $550 \mathrm{~nm}$ were at the detection limit of the instrument while measurements below $550 \mathrm{~nm}$ were not seriously affected. The precision of the regression based $a_{m}(500)$-estimate for the clearest water $\left(a_{m}[500]=0.011 \mathrm{~m}^{-1}\right.$, at $500 \mathrm{~m}$ depth in Sognefjorden $)$ corresponds to a $95 \%$ CI of about $\pm 20 \%$. For the average water clarity $\left(a_{m}[500]=0.059 \mathrm{~m}^{-1}\right)$ in our data set, $95 \%$ CI corresponds to $\pm 7 \%$.

Samples $(100 \mathrm{ml})$ for chlorophyll a (chl a) analysis were filtered through $0.45 \mu \mathrm{m}$ Sartorius filters, and frozen for later analysis using acetone extraction (Holm-Hansen et al. 1965).

Time-series of salinity and temperature. Since 1935 the Institute of Marine Research, Bergen, Norway has measured salinity and temperature approximately bi-

Table 1. Locations along the western coast of Norway where modified light absorption (see 'Materials and methods'), salinity, dissolved oxygen and chl a concentrations were measured in 2006

\begin{tabular}{|c|c|c|c|c|c|}
\hline Date & Location & $\begin{array}{l}\text { Lat. } \\
\left({ }^{\circ} \mathrm{N}\right)\end{array}$ & $\begin{array}{l}\text { Long. } \\
\left({ }^{\circ} \mathrm{E}\right)\end{array}$ & $\begin{array}{c}\text { Bottom } \\
\text { depth (m) }\end{array}$ & Sampling depth (m) \\
\hline 29 Oct & Lurefjorden & 60.41 & 5.10 & 439 & $10,20,40,60,100,150,200,250,300,400$ \\
\hline 30 Oct & Masfjorden & 60.52 & 5.25 & 483 & $10,20,40,60,100,150,200,250,300,400,450$ \\
\hline $1 \mathrm{Nov}$ & Sognefjorden & 61.08 & 6.06 & 1248 & $10,20,40,60,100,150,200,250,300,400,500,600,800,1000,1200$ \\
\hline $2 \mathrm{Nov}$ & Lysefjorden & 59.00 & 6.17 & 454 & $2,5,10,20,40,60,100,150,200,250,300,400$ \\
\hline $3 \mathrm{Nov}$ & Jøsenfjorden & 59.17 & 6.19 & 645 & $0,5,10,20,40,60,100,200,300,400,500,600$ \\
\hline $3 \mathrm{Nov}$ & Hylsfjorden & 59.31 & 6.18 & 503 & $0,5,10,20,40,60,100,200,300,400,450$ \\
\hline
\end{tabular}


monthly at the station Sognesjøen (Fig. 1, http://atlas. nodc.no/stasjoner/). This station is located close to Lurefjorden and Masfjorden, and we utilize the observations of salinity and sigma-t to estimate the effect of NCW freshening on the darkening of these 2 adjacent fjords.

Due to a shallow sill (20 m), the basin water of Lurefjorden (maximum depth $439 \mathrm{~m}$ ) contains NCW, which floats above the more saline and dense North Atlantic Water (NAW). The basin of this fjord is renewed by NCW that passes above the $20 \mathrm{~m}$ sill, while the deeper NAW is blocked by the shallow sill. Deep basin renewals take place at times when NCW is denser than the residing basin water, which becomes diluted with time due to vertical mixing. We consider sigma-t at $10 \mathrm{~m}$ depth at the Sognesjøen station (Fig. 1) to be indicative of the density of the water that renews with the basin water of Lurefjorden.

The sill depth (75 m) of Masfjorden is deeper than for Lurefjorden and the basin water of Masfjorden (maximum depth is $483 \mathrm{~m}$ ) consists of NAW, although in certain years the salinity of this fjord basin has been slightly affected by NCW and Norwegian Trench Water (Sørnes \& Aksnes 2006). We consider sigma-t at

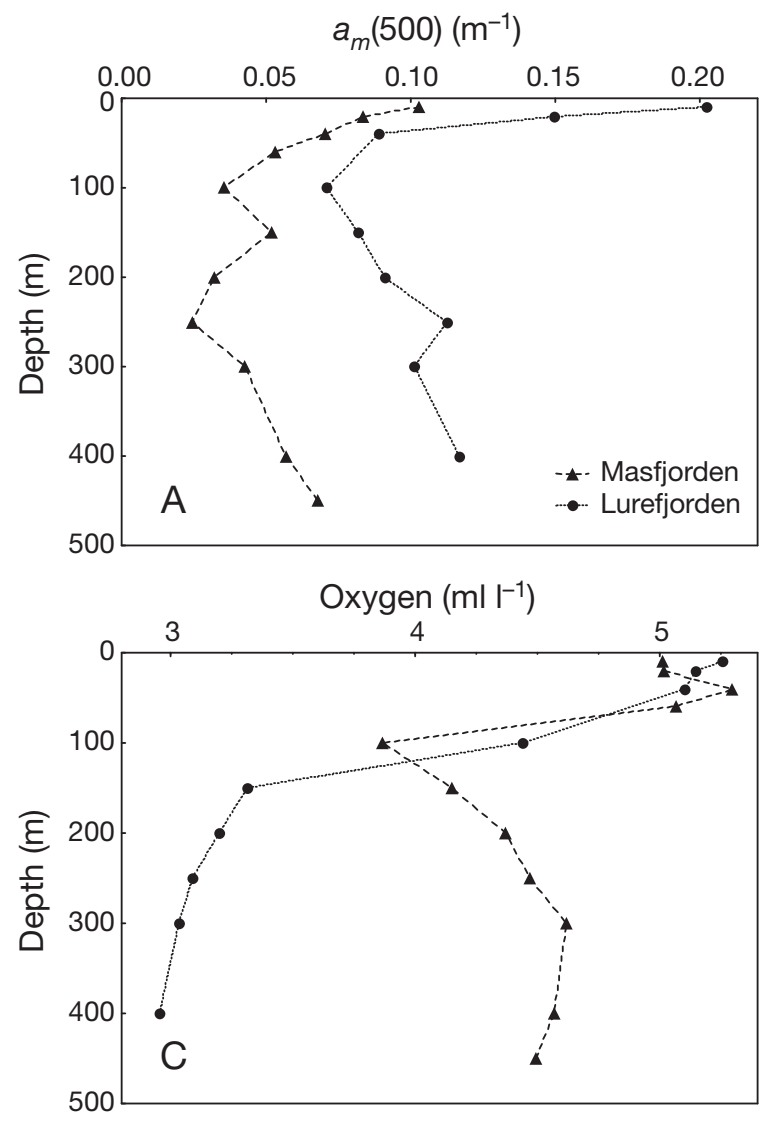

$50 \mathrm{~m}$ depth at the Sognesjøen station to be indicative for the density of the water that renews the basin of Masfjorden.

Statistical analyses. The absorption measurements were analyzed in a multiple regression analysis with observed salinity, chl $a$, and oxygen as the independent variables, and we tested for all possible interaction effects. The software package Statistica version 8 was used for this purpose.

\section{RESULTS}

\section{Comparison of Lurefjorden and Masfjorden}

The vertical profiles of $a_{m}(500)$ salinity, oxygen, chl $a$ are shown in Fig. 2. For all depths the $a_{m}(500)$ in Lurefjorden were much higher than in Masfjorden (Fig. 2A). The basin water of Lurefjorden contained NCW with salinity of $\sim 33$ PSU, while the basin water of Masfjorden contained NAW with salinity slightly above 35 PSU (Fig. 2B). The difference between the 2 basins was also reflected in the dissolved oxygen concentrations, with 3 to 3.3 and 4.2 to $4.6 \mathrm{ml} \mathrm{l}^{-1}$ below
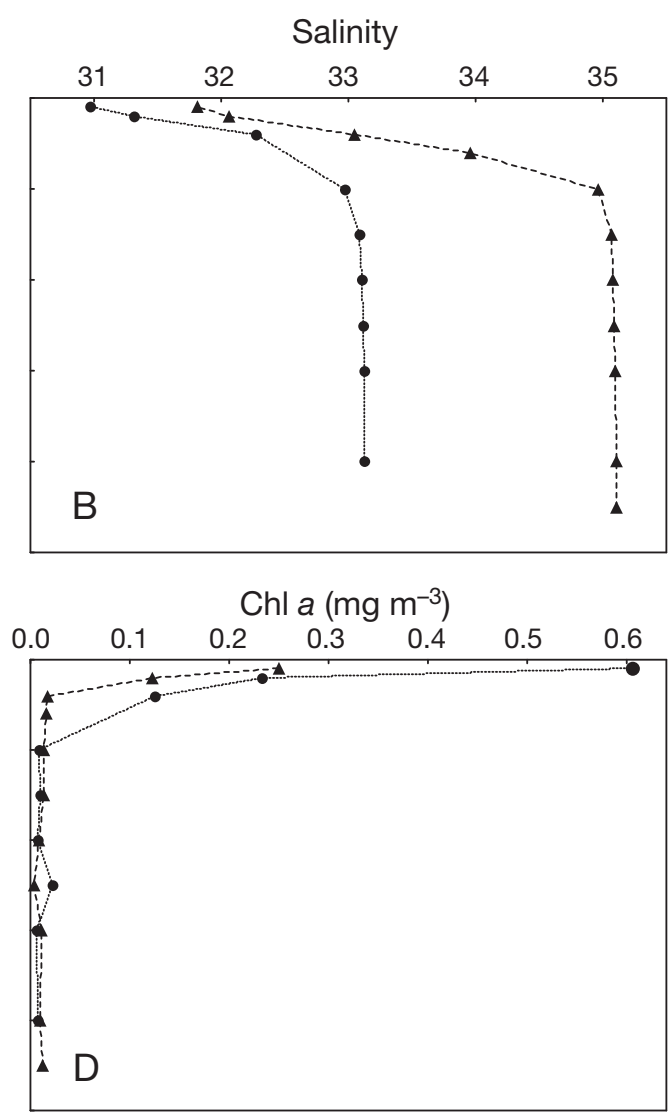

Fig. 2. Depth profiles of (A) $a_{m}$ (500) (see Eq. (1) for details), (B) salinity, (C) dissolved oxygen, and (D) chl a in Masfjorden (30 October 2006) and in Lurefjorden (29 October 2006) 
$150 \mathrm{~m}$ depth in Lurefjorden and Masfjorden, respectively (Fig. 2C). The chl a concentrations were low and similar in both basins, but higher in Lurefjorden close to the surface (Fig. 2D).

The measurements of downwelling irradiance at $500 \mathrm{~nm}$ suggest that light penetration down to $70 \mathrm{~m}$ was 20 times higher in Masfjorden than in Lurefjorden (Fig. 3). The linear regression analysis between the attenuation coefficients for downwelling irradiance calculated $\left(K_{d}[500]\right)$ from the observations in Fig. 3 (see 'Materials and methods') and the corresponding $a_{m}(500)$ measurements (Fig. 2A) yielded:

$K_{d}(500)=1.059 a_{m}(500)+0.013\left(\mathrm{r}=0.99, \mathrm{n}=7, \mathrm{p}<10^{-4}\right)$

which suggests that $a_{m}(500)$ is a good predictor for light attenuation for the depth range 10 to $80 \mathrm{~m}$.

\section{$a_{m}(500)$ as a function of salinity, oxygen and chl a}

The mean values and ranges of $a_{m}(500)$ and $k_{m}(500)$ (see Eq. 1) observed for the different fjord locations are shown in Table 2. A multiple regression analysis suggests that all $a_{m}(500)$ measurements can be expressed by the equation:

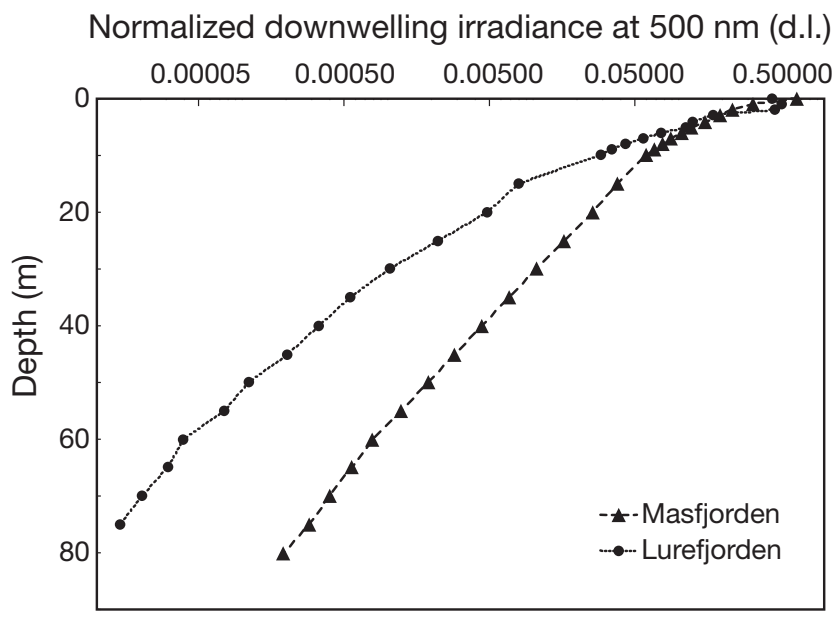

Fig. 3. Downwelling irradiance (given as a fraction of surface irradiance at $500 \mathrm{~nm}$ ) as a function of depth in Masfjorden (6 October 2006) and in Lurefjorden (11 October 2006)

$$
\begin{gathered}
a_{m}(500)=0.64-0.016 S-0.012 O_{2}+0.15 C h l \\
(\mathrm{r}=0.89, \mathrm{n}=70)
\end{gathered}
$$

where $\mathrm{S}_{1} \mathrm{O}_{2}$ and $\mathrm{Chl}$ are salinity, dissolved oxygen concentration $\left(\mathrm{ml} \mathrm{l}^{-1}\right)$ and $\mathrm{chl} \mathrm{a}\left(\mathrm{mg} \mathrm{m}^{-3}\right)$, respectively. All 3 effects were statistically significant and no inter-

Table 2. Mean values and ranges (in parentheses) of $a_{m}(500), k_{m}(500)$ (see 'Materials and methods'), salinity, oxygen and chl $a$ at

\begin{tabular}{|c|c|c|c|c|c|}
\hline & $a_{m}(500)\left(\mathrm{m}^{-1}\right)$ & $k_{m}(500)\left(\mathrm{nm}^{-1}\right)$ & Salinity & Oxygen $\left(\mathrm{ml} \mathrm{l}^{-1}\right)$ & $\mathrm{Chl} \mathrm{a}\left(\mathrm{mg} \mathrm{m}^{-3}\right)$ \\
\hline \multicolumn{6}{|l|}{ Depth > $100 \mathrm{~m}$} \\
\hline \multirow[t]{2}{*}{ Lurefjorden } & 0.101 & -0.010 & 33.11 & 3.1 & 0.010 \\
\hline & $(0.082,0.117)$ & $(-0.011,-0.009)$ & $(33.08,33.13)$ & $(3.0,3.1)$ & $(0.006,0.022)$ \\
\hline \multirow[t]{2}{*}{ Masfjorden } & 0.046 & -0.011 & 35.09 & 4.5 & 0.010 \\
\hline & $(0.024,0.068)$ & $(-0.016,-0.008)$ & $(35.07,35.11)$ & $(4.2,4.6)$ & $(0.004,0.013)$ \\
\hline \multirow[t]{2}{*}{ Sognefjorden } & 0.020 & -0.016 & 35.05 & 4.8 & 0.013 \\
\hline & $(0.010,0.039)$ & $(-0.023,-0.010)$ & $(35.05,35.01)$ & $(4.3,5.4)$ & $(0.011,0.015)$ \\
\hline \multirow[t]{2}{*}{ Lysefjorden } & 0.053 & -0.013 & 33.39 & 2.1 & 0.009 \\
\hline & $(0.025,0.093)$ & $(-0.018,-0.009)$ & $(33.32,33.42)$ & $(1.9,2.4)$ & $(0.008,0.012)$ \\
\hline \multirow[t]{2}{*}{ Jøsenfjorden } & 0.071 & -0.010 & 35.05 & 1.7 & 0.006 \\
\hline & $(0.031,0.099)$ & $(-0.013,-0.008)$ & $(35.04,35.08)$ & $(0.7,4.0)$ & $(0.005,0.008)$ \\
\hline \multirow[t]{2}{*}{ Hylsfjorden } & 0.075 & -0.008 & 35.06 & 3.7 & 0.007 \\
\hline & $(0.043,0.109)$ & $(-0.011,-0.007)$ & $(35.05,35.08)$ & $(3.1,4.2)$ & $(0.006,0.008)$ \\
\hline \multicolumn{6}{|l|}{ Depth $\leq 100 \mathrm{~m}$} \\
\hline \multirow[t]{2}{*}{ Lurefjorden } & 0.128 & -0.012 & 31.88 & 5.0 & 0.024 \\
\hline & $(0.071,0.203)$ & $(-0.013,-0.011)$ & $(30.97,32.97)$ & $(4.4,5.3)$ & $(0.009,0.606)$ \\
\hline \multirow[t]{2}{*}{ Masfjorden } & 0.069 & -0.012 & 33.17 & 4.9 & 0.084 \\
\hline & $(0.035,0.103)$ & $(-0.014,-0.010)$ & $(31.81,34.97)$ & $(3.9,5.3)$ & $(0.014,0.250)$ \\
\hline \multirow[t]{2}{*}{ Sognefjorden } & 0.045 & -0.014 & 32.93 & 5.3 & 0.195 \\
\hline & $(0.024,0.083)$ & $(-0.019,-0.010)$ & $(31.07,34.85)$ & $(5.1,5.5)$ & $(0.019,0.602)$ \\
\hline \multirow[t]{2}{*}{ Lysefjorden } & 0.131 & -0.011 & 31.36 & 4.7 & 0.265 \\
\hline & $(0.042,0.293)$ & $(-0.016,-0.009)$ & $(28.94,33.21)$ & $(2.9,5.8)$ & $(0.011,0.638)$ \\
\hline \multirow[t]{2}{*}{ Jøsenfjorden } & 0.094 & -0.011 & 33.00 & 4,8 & 0.060 \\
\hline & $(0.042,0.216)$ & $(-0.012,-0.010)$ & $(31.51,34,78)$ & $(4.7,5.0)$ & $(0.006,0.194)$ \\
\hline \multirow[t]{2}{*}{ Hylsfjorden } & 0.125 & -0.013 & 28.72 & 5.5 & 0.109 \\
\hline & $(0.031,0.416)$ & $(-0.018,-0.010)$ & $(14.59,34.97)$ & $(4.6,7.0)$ & $(0.011,0.347)$ \\
\hline
\end{tabular}
the 6 investigated locations (see Table 1) 
action effects were detected (Table 3). The beta-values, which are a measure of the relative contribution of each independent variable, were $-0.73,-0.23$, and 0.35 for salinity, oxygen, and chl $a$, respectively (negative sign indicates negative contribution to $a_{m}[500]$ ). This suggests that salinity had the highest overall effect on $a_{m}(500)$ in the present dataset. It should be noted however that this relationship represents a time of year (October/November) and depth range (10 to $1200 \mathrm{~m}$ ) where chl a concentrations were low (range 0.05 to 0.6 with mean $0.1 \mathrm{mg} \mathrm{chl} \mathrm{a} \mathrm{m}^{-3}$ ).

Eq. (3) implies that decreased dissolved oxygen concentration is accompanied by increased light absorption. In a multiple regression analysis we also obtained statistical significant effects on the spectral slope coefficient, $k_{m}$ (Eq. 1), from dissolved oxygen $\left(\mathrm{p}=5.310^{-4}\right)$ and chl $a(\mathrm{p}=0.02)$ but not from salinity (Table 4$)$. This suggests that the $a_{m}(500)$ of the higher wavelengths was relatively more affected than the lower wavelengths by a decrease in oxygen (Fig. 4).

\section{Long-term NCW freshening at Sognesjøen}

Although seasonal variation dominates the scatter, the salinity measurements obtained at $1 \mathrm{~m}$ depth at the

Table 3. Statistical significance (p-level) of the 4 coefficients in a multiple regression analysis (see Eq. 3). Dependent variable was $a_{m}(500)\left(\mathrm{m}^{-1}\right)$ and the independent variables were salinity, dissolved oxygen $\left(\mathrm{ml} \mathrm{l}^{-1}\right)$, and chl a $\left(\mathrm{mg} \mathrm{m}^{-3}\right)(\mathrm{n}=70)$. No significant $(p>0.05)$ interaction effects were found in a stepwise procedure that started with inclusion of all possible interaction effects and successive removal of the highest order non-significant interaction. The $\beta$-values are a measure of the relative contribution of each independent variable in the particular dataset (Table 1)

\begin{tabular}{lrccr|}
\hline & Coefficient & SE & p-level & $\beta$ \\
\hline Intercept & 0.644 & 0.058 & $<10^{-6}$ & \\
Salinity & -0.016 & 0.002 & $<10^{-6}$ & -0.73 \\
Oxygen & -0.012 & 0.003 & $9.1 \times 10^{-4}$ & -0.23 \\
Chl $a$ & 0.153 & 0.031 & $6.0 \times 10^{-6}$ & 0.35 \\
\hline
\end{tabular}

Table 4. Statistical significance (p-level) of the 4 coefficients in a multiple regression analysis where the spectral slope coefficient, $k_{m}$ (see Eq. 1), was the dependent variable and the independent variables were salinity, oxygen $\left(\mathrm{ml} \mathrm{l}^{-1}\right)$, and chl a $\left(\mathrm{mg} \mathrm{m}^{-3}\right)(\mathrm{n}=70)$

\begin{tabular}{|lccc|}
\hline & Coefficient & SE & p-level \\
\hline Intercept & -0.0002 & 0.0056 & 0.97 \\
Salinity & -0.0002 & 0.0002 & 0.15 \\
Oxygen & -0.0012 & 0.0003 & $5.3 \times 10^{-4}$ \\
Chl a & 0.0070 & 0.0030 & 0.02 \\
\hline
\end{tabular}
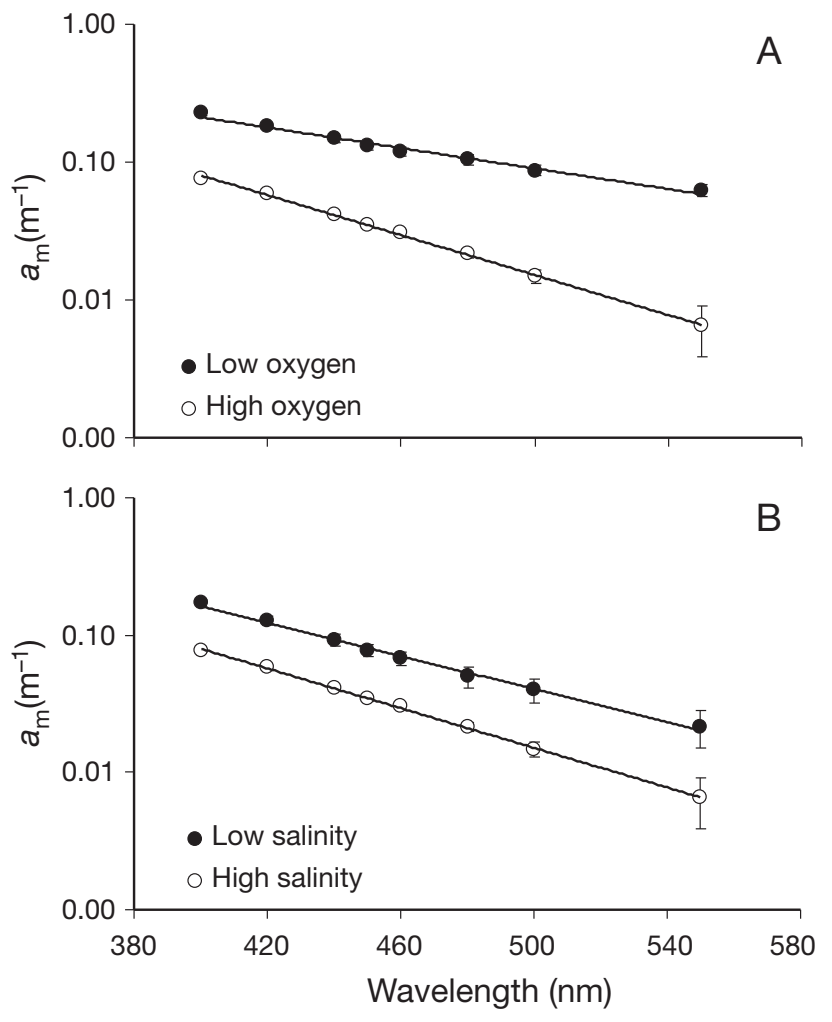

Fig. 4. $a_{m}(500)$ at different wavelengths for (A) low (0.7 to $1.0 \mathrm{ml} \mathrm{l}^{-1}$ ) and high (5.1 to $5.4 \mathrm{ml} \mathrm{l}^{-1}$ ) dissolved oxygen, but where salinity was approximately constant (35.03 to 35.10 ), and for (B) low (33.7 to 33.9) and high (35.03 to 35.10) salinity, but where oxygen was approximately constant (5.1 to $5.4 \mathrm{ml}$ $\mathrm{l}^{-1}$ ). Chl a was lower than $0.015 \mathrm{mg} \mathrm{m}^{-3}$ in all samples. The exponents of the fitted exponential equation (see Eq. 1) were $k_{m}=-0.0166 \pm 0.0002, \mathrm{r}^{2}=0.998$ (high oxygen in A and high salinity in B), $k_{m}=-0.0086 \pm 0.0004, \mathrm{r}^{2}=0.984$ (low oxygen in $\mathrm{A}$ ), and $k_{m}=-0.0139 \pm 0.0004, \mathrm{r}^{2}=0.994$ (low salinity in B)

Sognesjøen station (Fig. 1) suggest an overall decrease of 1 PSU over the period 1935 to 2007 (Fig. 5). At $10 \mathrm{~m}$ depth the freshening corresponds to 0.6 PSU. At $50 \mathrm{~m}$ depth, however, no long-term freshening is apparent (Fig. 5).

\section{Estimated effect of NCW freshening on darkening in Lurefjorden and Masfjorden}

The water masses that periodically renew the basins of Lurefjorden and Masfjorden have to pass over sills that are 20 and $75 \mathrm{~m}$ deep, respectively. We will assume that the salinity of these basins corresponds to the salinity of the water masses that intrude from 10 and $50 \mathrm{~m}$ depths at the Sognesjøen station, respectively (see 'Materials and methods'). The sigma-t at $10 \mathrm{~m}$ peaks in January to April (Fig. 6), suggesting that the renewal of the Lurefjorden basin is likely to occur at this time of the year. 

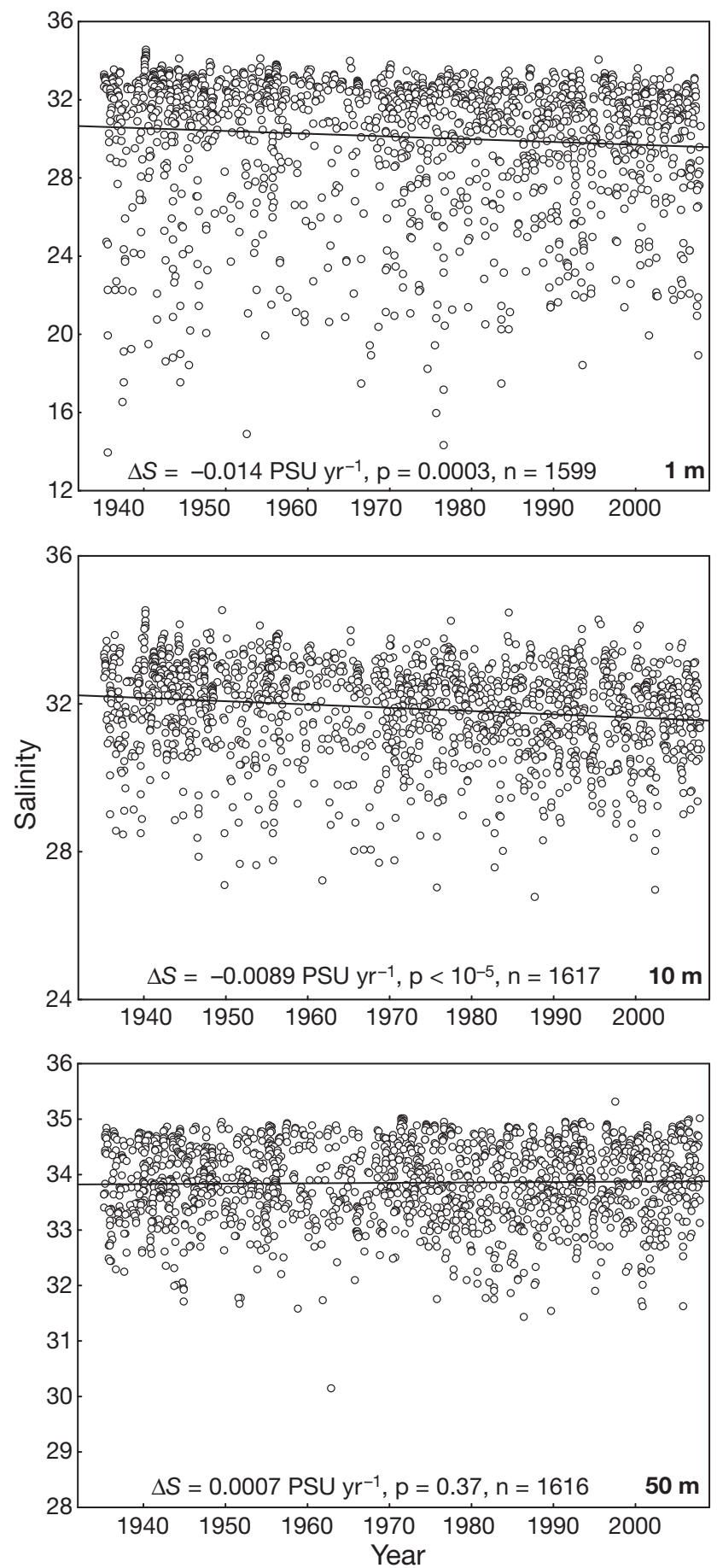

Fig. 5. Observations of salinity at 1,10 and $50 \mathrm{~m}$ depth at the Sognesjøen station. The slopes of the fitted lines are indicated by $\Delta S$

Over $73 \mathrm{yr}$ an increase in $a_{m}(500)$ from 0.043 to $0.055 \mathrm{~m}^{-1}$ is indicated for Lurefjorden (Fig. 7), which, according to Eq. (2), corresponds to an increase in $K_{d}(500)$ from 0.059 to $0.071 \mathrm{~m}^{-1}$. This implies a 2 orders of magnitude darkening at the bottom of the $439 \mathrm{~m}$ deep Lurefjorden (i.e. the amount of irradiance that

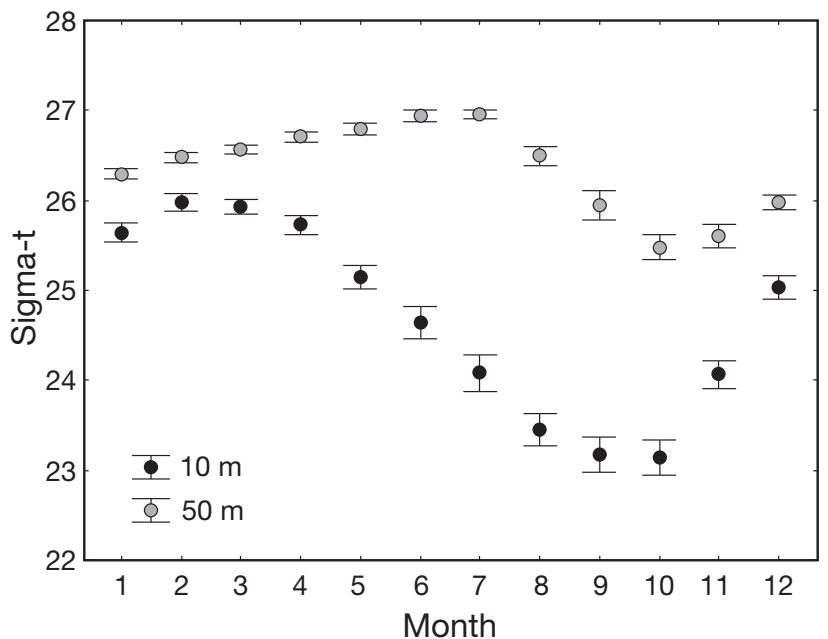

Fig. 6. Mean seasonal variation in sigma-t at 10 and $50 \mathrm{~m}$ depths at the Sognesjøen station obtained for the period 1935 to 2007 . The $10 \mathrm{~m}$ depth is assumed to represent the source water for the Lurefjorden basin, while the $50 \mathrm{~m}$ depth is assumed to represent the source water for the Masfjorden basin (see 'Materials and methods')

penetrates to this depth is reduced by a factor of 194). It should be noted that this approximation reflects the freshening effect only and not possible effects from changes in oxygen and pigment concentration that might have occurred over the $73 \mathrm{yr}$.

The sigma-t at $50 \mathrm{~m}$ at the Sognesjøen station peaks in April to July (Fig. 6), which is the likely renewal period for the Masfjorden basin. No freshening-associated change in $a_{m}(500)$ was detected for this basin (Fig. 7), suggesting the darkening of this fjord has been limited to that caused by freshening of the upper part of the water column where NCW is present. It should be noted, however, that annual variations in oxygen concentration have been observed in this fjord with consequences for basin water light attenuation (Sørnes \& Aksnes 2006).

\section{DISCUSSION}

We have shown that salinity and dissolved oxygen, in addition to chlorophyll, can serve as proxies for the light attenuation in coastal waters of Norway, and that freshening and oxygen decline are accompanied with increased light attenuation. Yellow substances associated with fresh water runoff have long been recognized as an important contributor to the light attenuation of coastal water (Sverdrup et al. 1942) and this is reflected in the optical classification scheme of marine waters (Jerlov 1968). The observed negative correlation between light absorption and oxygen appears to be less known. The dissolved oxygen concentration of a fjord basin is affected by the actual organic load and 


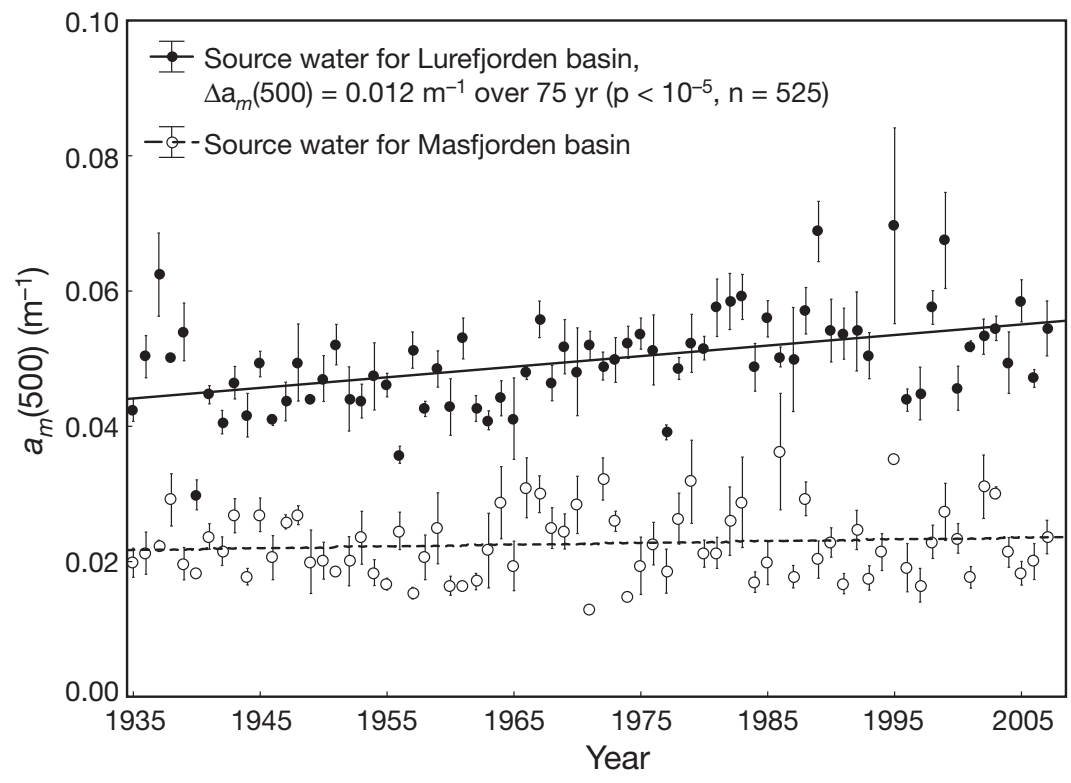

Fig. 7. Calculated effect of Norwegian Coastal Water (NCW) freshening on light attenuation in the fjord basins of Lurefjorden and Masfjorden. Annual means $( \pm \mathrm{SE})$ of $a_{m}(500)$ for Lurefjorden and Masfjorden were calculated according to Eq. (3), where dissolved oxygen $\left(\mathrm{O}_{2}\right)$ and chl a concentrations $(\mathrm{Chl})$ were constant at $6 \mathrm{ml} \mathrm{l}^{-1}$ and $0 \mathrm{mg} \mathrm{m}^{-3}$, respectively, for the entire-time series. Thus variations in $a_{m}(500)$ reflect the variation in the salinity of the source water of the 2 fjords and possible long-term trends in dissolved oxygen, browning, and phytoplankton biomass are not accounted for (see 'Discussion'). The source water for Lurefjorden was defined as the water at $10 \mathrm{~m}$ depth at the Sognesjøen station in the period January-April, while $50 \mathrm{~m}$ depth (May-July) was the defined source water for Masfjorden (see 'Materials and methods')

Table 4), although our wavelength region (400 to $550 \mathrm{~nm}$ ) was different from those in Helms et al. (2008) (275 to 295 and 350 to $400 \mathrm{~nm}$ ).

Our results suggest that moderate variations in salinity and oxygen can be associated with variations in light penetration spanning several orders of magnitude due to the integrative effect of light attenuation. The light attenuation above a certain depth not only affects the light intensity at this depth, but also at all depths below. In Table 5 we give the fraction of downwelling irradiance that penetrates through a $200 \mathrm{~m}$ hypothetical water column with no chl a but where salinity and dissolved oxygen vary over the ranges 33 to $35 \mathrm{PSU}$ and 1 to $6 \mathrm{ml} \mathrm{l}^{-1}$, respectively. The difference between the clearest and the darkest water is striking (8 orders of magnitude) and our results suggest that an oxygen drop from 6 to $3 \mathrm{ml} \mathrm{l}^{-1}$ affects light penetration similarly to a salinity drop from 35 to 33 .

\section{Has coastal water darkening facilitated mesopelagic regime shifts?}

It has been shown previously that

the turnover time of the basin water (Stigebrandt et al. 1996), and a low oxygen concentration is indicative of waters where microbial degradation of POM to DOM has occurred for some time. Elevated concentrations of degraded DOM might explain why the $a_{m}(500)$ values are negatively correlated with oxygen concentration in the investigated fjord basins (Sørnes \& Aksnes 2006). Interestingly, Yamashita \& Tanoue (2008, p 579) concluded that fluorescent dissolved organic matter is produced in situ in the ocean interior, along with biological oxidization of organic matter, and that it is resistant to biological degradation on centennial to millennial timescales. This suggests that a relationship between light attenuation and dissolved oxygen might be a general feature of deep waters. Helms et al. (2008) showed that aerobic microbial alteration of CDOM in darkness resulted in a change in spectral slope characterized by higher absorption at the longer wavelengths. This might explain the effect of low oxygen on the spectral slope in our study (Fig. 4A,
Table 5. Fraction $(f)$ of downwelling irradiance $(500 \mathrm{~nm})$ that penetrates a $200 \mathrm{~m}$ hypothetical water column with different salinity and oxygen characteristics. Here, $f=\mathrm{e}^{-200 K_{d}(500)}$ where $K_{d}(500)$ was calculated from Eqs. (2) \& (3) with chl $a$ concentration set at 0

\begin{tabular}{|lccccc|}
\hline \multirow{2}{*}{$\begin{array}{l}\text { Oxygen } \\
\left(\mathrm{ml} \mathrm{l}^{-1}\right)\end{array}$} & 33 & 33.5 & 34 & 34.5 & 35 \\
\hline & \multicolumn{5}{c}{ Salinity } \\
\hline 1 & $2.0 \times 10^{-11}$ & $1.1 \times 10^{-10}$ & $6.0 \times 10^{-10}$ & $3.3 \times 10^{-9}$ & $1.8 \times 10^{-8}$ \\
2 & $2.6 \times 10^{-10}$ & $1.4 \times 10^{-9}$ & $7.6 \times 10^{-9}$ & $4.1 \times 10^{-8}$ & $2.2 \times 10^{-7}$ \\
3 & $3.3 \times 10^{-9}$ & $1.8 \times 10^{-8}$ & $9.6 \times 10^{-8}$ & $5.2 \times 10^{-7}$ & $2.9 \times 10^{-6}$ \\
4 & $4.1 \times 10^{-8}$ & $2.2 \times 10^{-7}$ & $1.2 \times 10^{-6}$ & $6.7 \times 10^{-6}$ & $3.6 \times 10^{-5}$ \\
5 & $5.2 \times 10^{-7}$ & $2.9 \times 10^{-6}$ & $1.6 \times 10^{-5}$ & $8.5 \times 10^{-5}$ & $4.6 \times 10^{-4}$ \\
6 & $6.7 \times 10^{-6}$ & $3.6 \times 10^{-5}$ & $2.0 \times 10^{-4}$ & $1.1 \times 10^{-3}$ & $5.8 \times 10^{-3}$ \\
\hline
\end{tabular}


with NCW freshening, is sufficient to have caused regime shift involving the observed mass occurrence of Periphylla periphylla (Fosså 1992, Sørnes et al. 2007). However, this darkening might be underestimated, as unaltered pigment and oxygen concentration over the period 1935 to 2006 were assumed. Combined with freshening, a hypothetical average decline in dissolved oxygen of $1 \mathrm{ml} \mathrm{l}^{-1}$ in this period suggests a 5-, instead of 2-, order-of-magnitude darkening. Baliño \& Aksnes (1993) observed that the mesopelagic fish Maurolicus muelleri has a preference for light on the order $10^{-3}$ to $10^{-5}$ (given as a fraction of daytime surface light, Table 6), while evidence (Sørnes et al. 2007) suggest that the preference of $P$. periphylla is several orders of magnitude lower (Table 6). Fjords containing clear Atlantic Water (salinity > 35 and high dissolved oxygen concentration) must be much deeper than 500 $\mathrm{m}$ in order to satisfy such preference for low light. The results in Table 5, however, indicate that combined freshening and oxygen decline can effectively provide darkness in shallow fjords.

Nevertheless, more observations are obviously needed to test whether coastal water darkening has favored tactile predators like Periphylla periphylla over visual predators like Maurolicus muelleri. In recent years there has been an increase in the number of locations with mass occurrences of $P$. periphylla along the Norwegian coast (J. A. Sneli, C. Schander, K. Eiane pers. comm.). Each of these represents an opportunity to test whether the occurrences are consistent with the 'darkening hypothesis' or whether some of these occur in environments where darkening can be excluded. Locations where time-series of both salinity and oxygen can serve as proxies would be particularly useful to address effects of darkening on marine food web structure in Norwegian coastal areas and elsewhere.

\section{Other factors affecting water column darkening}

Altered patterns in precipitation and freshwater runoff are expected from climate change and global warming, yet so far the potential effect of associated changes in water clarity on marine ecosystems have not received much focus. Added to variation in runoff patterns, several studies suggest a 'browning' of freshwater around the North Sea, but also of waters entering coastal areas in general (Evans et al. 2005, Roulet \& Moore 2006, Monteith et al. 2007). Such browning is caused by elevated concentrations of DOM. For UK upland waters, Evans et al. (2006) report a $91 \%$ increase in DOC from 1988 up to 2003, but due to a lack of longer time-series the duration of this browning is uncertain. The increased light attenuation indicated in Fig. 7 does not account for such browning and might therefore underestimate the actual NCW darkening, at least in recent years.

Increased marine production associated with eutrophication also implies a darkening of coastal water due to increased pigment concentration as well as a general increase in POM and DOM. Based on observations extending back to 1919, Sanden \& Håkansson (1996)

Table 6. Approximated light preferences for the jellyfish Periphylla periphylla and the mesopelagic fish Maurolicus muelleri. Observations of the mean depth of the daytime vertical distribution of $P$. periphylla and the light absorbance values in Lurefjorden are from Table 4 in Sørnes et al. (2007). Their reported light absorbance measurements $\left(A_{[400-550]}\right)$ represented the average of the 400 to $550 \mathrm{~nm}$ range averaged over 100 to $300 \mathrm{~m}$ depth. We obtained the following relationship between $a_{m}(500)$ and $A_{(400-500)}: a_{m}(500)=-0.008+1.51 A_{(400-500)}\left(\mathrm{n}=70, \mathrm{r}^{2}=0.95, \mathrm{p}<10^{-3}\right)$ for our data set and used this relationship to transform the measurements reported in Sørnes et al. (2007) into $a_{m}(500)$. Our Eq. (2) was used to approximate $K_{d}(500)$. The light preference in the last column represents the fraction of light penetrating down to the mean depth of the $P$. periphylla vertical distribution at daytime, i.e. $f=\exp \left(-K_{d}(500) \times Z_{m}\right)$. The light preferences of $M$. muelleri correspond to the midday isolume depth reported in Fig. 5 of Baliño \& Aksnes (1993)

\begin{tabular}{|c|c|c|c|c|}
\hline & $\begin{array}{l}\text { Mean depth } \\
Z_{m}, \mathrm{~m}\end{array}$ & $\begin{array}{l}\text { Light absorbance } \\
\qquad A_{(400-500)}, \mathrm{m}^{-1}\end{array}$ & $\begin{array}{l}\text { Light attenuation } \\
K_{d}(500), \mathrm{m}^{-1}\end{array}$ & $\begin{array}{l}\text { Light preference } \\
(f)\end{array}$ \\
\hline \multicolumn{5}{|l|}{ P. periphylla $(<4 \mathrm{~cm})$} \\
\hline Lurefjorden & 172 & $0.077 \pm 0.001$ & 0.127 & $10^{-10}$ \\
\hline Sognefjorden & 947 & $0.020 \pm 0.003$ & 0.036 & $10^{-15}$ \\
\hline Halsafjorden & 276 & $0.061 \pm 0.004$ & 0.102 & $10^{-12}$ \\
\hline Mean & & & & $10^{-12}$ \\
\hline \multicolumn{5}{|l|}{ P. periphylla $(>4 \mathrm{~cm})$} \\
\hline Lurefjorden & 140 & $0.077 \pm 0.001$ & 0.13 & $10^{-8}$ \\
\hline Sognefjorden & 584 & $0.020 \pm 0.003$ & 0.04 & $10^{-9}$ \\
\hline Halsafjorden & 280 & $0.061 \pm 0.004$ & 0.10 & $10^{-13}$ \\
\hline Mean & & & & $10^{-10}$ \\
\hline M. muelleri (juvenile) & & & & $10^{-3}$ \\
\hline M. muelleri (adult) & & & & $10^{-5}$ \\
\hline
\end{tabular}


reported a significant shoaling of the Secchi disc depth in the Baltic Sea during the 20th century. They concluded that this shoaling could be due to an increase in humic substances but was more likely induced by increased phytoplankton biomass. Again, our NCWdarkening estimate does not account for eutrophication effects and increased phytoplankton biomass, which also suggests that the actual darkening has been higher than that indicated in Fig. 7.

\section{CONCLUSION}

Our study suggests that the NCW freshening has been associated with a water column darkening that has been most pronounced at coastal locations where NCW penetrates down to large depths, such as Lurefjorden. Such locations are also vulnerable to oxygen declines that according to our results can magnify the darkening quite substantially. Due to absence of optical time-series we believe that water column darkening has been underrated as a driving force for food web changes in coastal areas around the world. Development of optical proxies, including salinity and oxygen variations, browning, and eutrophication, together with available Secchi depth observations represent an opportunity to assess the significance of changing optics in coastal ecosystems.

Acknowledgements. This work was sponsored in part by the Marie Curie Early Stage Training Network METAOCEANS (MEST-CT-2005-019678). We thank A. Folkvord and 3 anonymous reviewers for valuable suggestions.

\section{LITERATURE CITED}

Aarup T, Holt N, Højerslev NK (1996) Optical measurements in the North Sea-Baltic Sea transition zone. (2) Water mass classification along the Jutland west coast from salinity and spectral irradiance measurements. Cont Shelf Res 16: 1343-1353

Aksnes DL (2007) Evidence for visual constraints in large marine fish stocks. Limnol Oceanogr 52:198-203

Aksnes DL, Ohman MD (2009) Multidecadal shoaling of the euphotic zone in the southern sector of the California Current System. Limnol Oceanogr 54:1272-1281

Aksnes DL, Nejstgaard J, Sædberg E, Sørnes T (2004) Optical control of fish and zooplankton populations. Limnol Oceanogr 49:233-238

Aksnes DL, Ohman MD, Riviere P (2007) Optical effect on the nitracline in a coastal upwelling area. Limnol Oceanogr 52:1179-1187

Aure J, Danielssen D, Sætre R (1996) Assessment of eutrophication in Skagerrak coastal waters using oxygen consumption in fjordic basins. ICES J Mar Sci 53:589-595

Baliño BM, Aksnes DL (1993) Winter distribution and migration of the sound scattering layers, zooplankton and micronekton in Masfjorden, western Norway. Mar Ecol Prog Ser 102:35-50
Bagøien E, Kaartvedt S, Aksnes DL, Eiane K (2001) Vertical distribution and mortality of overwintering Calanus. Limnol Oceanogr 46:1494-1510

Daskalov GM, Grishin AN, Rodionov S, Mihneva V (2007) Trophic cascades triggered by overfishing reveal possible mechanisms of ecosystem regime shifts. Proc Natl Acad Sci USA 104:10518-10523

Diaz RJ (2001) Overview of hypoxia around the world. J Environ Qual 30:275-281

Eiane K, Aksnes DL, Bagøien E, Kaartvedt S (1999) Fish or jellies-a question of visibility? Limnol Oceanogr 44: $1352-1357$

> Evans CD, Monteith DT, Cooper DM (2005) Long-term increases in surface water dissolved organic carbon: observations, possible causes and environmental impacts. Environ Pollut 137:55-71

Evans CD, Chapman PJ, Clark JM, Monteith DT, Cresser MS (2006) Alternative explanations for rising dissolved organic carbon export from organic soils. Glob Change Biol 12:2044-2053

Falkowski PG, Wilson C (1992) Phytoplankton productivity in the North Pacific Ocean since 1900 and implications for absorption of anthropogenic $\mathrm{CO}_{2}$. Nature 358:741-743

Fosså JH (1992) Mass occurrence of Periphylla Periphylla (Scyphozoa, Coronatae) in a Norwegian Fjord. Sarsia 77 : $237-251$

Frank TM, Widder EA (1994) Comparative study of behavioral sensitivity thresholds to near-Uv and blue-green light in deep-sea crustaceans. Mar Biol 121:229-235

Frette O, Erga SR, Hamre B, Aure J, Stamnes JJ (2004) Seasonal variability in inherent optical properties in a western Norwegian fjord. Sarsia 89:276-291

Gallegos CL, Jordan TE, Hines AH, Weller DE (2005) Temporal variability of optical properties in a shallow, eutrophic estuary: seasonal and interannual variability. Estuar Coast Shelf Sci 64:156-170

Greene CH, Pershing AJ, Cronin TM, Ceci N (2008) Arctic climate change and its impact on the ecology of the north Atlantic. Ecology 89:24-38

Helms JR, Stubbins A, Ritchie JD, Minor EC, Kieber DJ, Mopper K (2008) Absorption spectral slopes and slope ratios as indicators of molecular weight, source, and photobleaching of chromophoric dissolved organic matter. Limnol Oceanogr 53:955-969

Hernandez-Leon S (2008) Natural variability of fisheries and lunar illumination: a hypothesis. Fish Fisheries 9:138-154

> Højerslev NK, Holt N, Aarup T (1996) Optical measurements in the North Sea-Baltic Sea transition zone. (1) On the origin of the deep water in the Kattegat. Cont Shelf Res 16: 1329-1342

Holm-Hansen O, Lorenzen CJ, Holmes RW, Strickland JDH (1965) Fluorometric determination of chlorophyll. ICES J Mar Sci 30:3-15

> Holzman R, Genin A (2005) Mechanisms of selectivity in a nocturnal fish: a lack of active prey choice. Oecologia 146: 329-336

Jackson JBC (2001) What was natural in the coastal oceans? Proc Natl Acad Sci USA 98:5411-5418

Jerlov NG (1968) Optical oceanography. Elsevier Oceanography Series, Vol. 5. Elsevier Publishing Company, Amsterdam

Johannessen T, Dahl E (1996) Declines in oxygen concentrations along the Norwegian Skagerrak coast, 1927-1993: A signal of ecosystem changes due to eutrophication? Limnol Oceanogr 41:766-778

Kemp WM, Batiuk R, Bartleson R, Bergstrom P and others (2004) Habitat requirements for submerged aquatic vege- 
tation in Chesapeake Bay: Water quality, light regime, and physical-chemical factors. Estuaries 27:363-377

Monteith DT, Stoddard JL, Evans CD, de Wit HA and others (2007) Dissolved organic carbon trends resulting from changes in atmospheric deposition chemistry. Nature 450: 537-539

Nordberg K, Gustafsson M, Krantz AL (2000) Decreasing oxygen concentrations in the Gullmar Fjord, Sweden, as confirmed by benthic foraminifera, and the possible association with NAO. J Mar Syst 23:303-316

Pozdnyakov DV, Johannessen OM, Korosov AA, Pettersson LH, Grassl H, Miles MW (2007) Satellite evidence of ecosystem changes in the White Sea: A semi-enclosed arctic marginal shelf sea. Geophys Res Lett 34 L08604, doi:10. 1029/2006GL028947

Roulet N, Moore TR (2006) Environmental chemistryBrowning the waters. Nature 444:283-284

Sætre R (2007) The Norwegian Coastal Current. Tapir Academic Press, Trondheim

Sætre R, Aure J, Danielssen DS (2003) Long-term hydrographic

Editorial responsibility: Peter Verity,

Savannah, Georgia, USA variability off the Norwegian coast and on Skagerrak. ICES Mar Sci Symp 219:150-159

Sanden P, Håkansson B (1996) Long-term trends in Secchi depth in the Baltic Sea. Limnol Oceanogr 41:346-351

Stigebrandt A, Aure J, Molvær J (1996) Oxygen budget methods to determine the vertical flux of particulate organic matter with application to the coastal waters of western Scandinavia. Deep-Sea Res II 43:7-21

Sverdrup HU, Johnson MW, Fleming RH (1942) The oceans. Prentice Hall, New York

Sørnes TA, Aksnes DL (2006) Concurrent temporal patterns in light absorbance and fish abundance. Mar Ecol Prog Ser 325:181-186

Sørnes TA, Aksnes DL, Bamstedt U, Youngbluth MJ (2007) Causes for mass occurrences of the jellyfish Periphylla periphylla: a hypothesis that involves optically conditioned retention. J Plankton Res 29:157-167

Yamashita Y, Tanoue E (2008) Production of bio-refractory fluorescent dissolved organic matter in the ocean interior. Nature Geosci 1:579-582

Submitted: November 25, 2008; Accepted: May 20, 2009 Proofs received from author(s): July 20, 2009 